\title{
The Impact of Political Connection on Earnings Management in China's Private Enterprises
}

\author{
Zhiyuan Liao ${ }^{1}$, Weijian Zhang ${ }^{1}, \&$ Xiaohui Tao ${ }^{1}$ \\ ${ }^{1}$ Finance Department of International Business School, Jinan University, China \\ Correspondence: Weijian Zhang, Finance Department of International Business School, Jinan University, \\ Qianshan Road 206\#, Zhuhai City, Guangdong Province, Post NO. 519070, China.
}

Received: April 2, 2020

doi:10.5539/ibr.v13n6p128

\author{
Accepted: May 14, $2020 \quad$ Online Published: May 25, 2020 \\ URL: https://doi.org/10.5539/ibr.v13n6p128
}

\begin{abstract}
Earnings management behaviour lowers the quality of accounting information of private enterprises to a certain extent. Hence, it is necessary to study the relationship between political connection and earnings management of private enterprises. Through the investigation and statistics of the private companies in China's Small and Medium-sized Enterprise Board Market from 2013 to 2017, this paper performs empirical analysis to verify the relationship between political connection and earnings management. It shows that political connection can weaken accrual-based earnings management level, which helps private firms obtain more preferential policies and financing help. Based on the above conclusions, this paper puts forward the corresponding policy recommendations, which provide reference for the governance of private enterprises and the capital market.
\end{abstract}

Keywords: political connection, earnings management, private enterprises, corporate governance

\section{Introduction}

After the economic reform and opening in China, the development of private enterprises has become a vital force to promote national taxes, relieving social employment pressure, stabilizing social and economic operation (Wang et al., 2005). However, at present, the market mechanism still needs to be improved. There are still many private enterprises trying to establish some contacts with the government to obtain better developmental convenience, which we call political connection. Some benefits derived by political rent-seeking cannot be directly reflected in the financial statements, but need to be covered up through earnings management. As the development of the privately held company has a significant impact on the social economy and capital market, it is essential to study the impact of private enterprises' political connection on earnings management behaviour.

Most corporates choose to use accrual-based earnings management for their long-term development, which has little impact on enterprise value. However, with the improvement of accounting standards and systems and the strengthening of the external regulatory environment, space for enterprises to carry out accrual-based earnings management is becoming more and more limited, and the risks that the market can identify it are also increasing. Enterprises have the trend of turning from accrual-based earnings management to real earnings management. This paper takes the private listed companies in small and medium-size as a sample to conduct an in-depth study. It tries to explore whether the political connection is related to the earnings management behaviour of private enterprises in the rapid development of private economy. And it also attempts to figure out what kind of earnings management the enterprises prefer. This paper verifies the impact of government connection on earnings management behaviour through the combination of the theory and empirical analysis, which is of great significance for the development of private enterprises.

\section{Literature Review}

Enterprises often need to maintain a good relationship with various stakeholders in the production and operation, among which the government is one of the critical parts. A large number of studies have proved that political connections are common in both domestic and foreign enterprises. Faccio (2006) believed that if the controlling shareholder or the executive members of the company are Congressmen or Ministers, the company can be identified as having political connections. Claessens (2008) believed that corporates' contribution to the government during the election could measure relationships between enterprises and the government. In China, Zhang Duolei and Liu Yongze (2016) believed that not only the chairman of the board but also other executives 
play an essential role in company management. If they were or are holding government positions, then, there is a political connection.

At present, China's market mechanism is not perfectly developed, and the government still has an economic intervention. The existing research shows that the establishment of political ties with the government is conducive to excellent communication between enterprises and local relevant departments. On the one hand, it can obtain policy preferences and related subsidies; on the other hand, it can increase more financing opportunities for enterprises to achieve the purpose of reducing financing constraints. Wan Xiaoyun (2018) has mentioned that the government provides preferential taxes for politics related enterprises, which can reduce the tax burden of companies to a certain extent and improve business performance. Hu Xuyang (2010) has proved that the establishment of political connections among private firms can strengthen the relationship and help to obtain external credit resources.

The concept of earnings management has been widely discussed. According to Healy and Wahlen (1999), earnings management refers to the misleading by companies so stakeholders could not know the specific economic benefits of the company. At present, there are two common ways of earnings management, which are accrual-based earnings management and real earnings management, which have their advantages and disadvantages. Zhang Weiqiang (2019) mentioned that moderate earnings management could help improve the level of financial management. Cao ran (2019) mentioned that the choice of earnings management bases on its operation. Different enterprises with different operating conditions have different motivations of earnings management, so empirical analysis of private firms' earnings management behaviour preference has specific research significance.

Foreign scholars Chaney, Faccio, and Parsley (2011) found that the quality of accounting information in financial reports of politically connected firms was significantly lower than that of similar non-connected firms. In China, due to the different institutional environment, Sun Jinping (2018) mentioned that local officials might exert a negative impact on the quality of accounting information of politically connected firms for the sake of performance. Tao Xionghua (2018) and others found that the political connection of private listed companies has a particularly protective effect on earnings management, which can promote earnings management by reducing debt financing costs and external audit opinions. On the contrary, Cui Meng (2018) believed that political connection brings private corporates media attention, which can reduce accrual-based earnings management.

Through the literature review, we can find that with the rapid development of China's private economy, private enterprises still have many obstacles. With the improvement of supervision measures, enterprises gradually change from accrual-based earnings management to real earnings management. This paper analyzes the relationship between political connection and earnings management using empirical analysis, providing reference for the governance of private enterprises and the capital market.

\section{Hypothesis Development}

\subsection{The Preference for Earnings Management in Private Enterprises}

Wang Liangcheng (2014) believed that there is a specific relationship between accrual-based earnings management and real earnings management, which is not the relationship of mutual substitution. Li Chuntao (2016) believed that with the continuous strengthening of external supervision, the level of accrual earning management declined, forcing enterprises to turn to a more concealed ways of real earnings management. According to the existing literature and research data, managers use different methods of earnings management for their interests and reduce risks to be identified. Therefore, it is imperative to study what kind of earnings management is preferred by private enterprises. Based on the above analysis, the following assumptions are proposed.

Hypothesis 1: the level of accrual-based earnings management of private companies is lower than that of real earnings management, that is, private enterprises tend to choose real earnings management.

\subsection{The Influence of Political Connection on the Accrual-Based Earnings Management of Private Enterprises}

The political connection draws external attention to private enterprises, which increases the risk of manipulating accruals recognized by the market. To some extent, the political connection affects the earnings management behaviour of enterprises. The extra economic benefits obtained by unfair political rent-seeking cannot be directly reflected in the financial statements, which need to be covered up by certain earnings management behaviours. Nevertheless, good political connections can make enterprises obtain certain advantages in resource allocation. Therefore, this paper argues that political connection intensity may weaken the level of accrual-based earnings management of private enterprises. Based on the above analysis, the following assumptions are proposed. 
Hypothesis 2: political connection has a negative correlation with the accrual-based management of private enterprises, which means it can weaken the accrual-based management level.

\subsection{The Influence of Political Connection on The Real Earnings Management of Private Enterprises}

For private companies and entrepreneurs with political backgrounds, they pay more attention to the brand image and reputation of enterprises. $\mathrm{Li} \mathrm{Li}$ (2018) proposed that earnings management behaviour of listed companies can improve their status, which enhances the confidence of external accounting information users and the intrinsic value of enterprises. With the enhancement of enterprises' risk tolerance, private firms or entrepreneurs can establish contact with the government. On the one hand, they can create a high-quality corporate social image. On the other hand, the government can provide credit guarantee for them, solve their financing problems, and provide them with preferential tax policies to promote the healthy development of enterprises. Therefore, it is true that real earnings management is of necessity for private enterprises. Based on the above analysis, the following assumptions are proposed.

Hypothesis 3: political connection is positively related to the real earnings management of private companies, which means the political connection can promote the real earnings management level of private corporates.

\section{Empirical Verification}

\subsection{Variable Definition and Designed Model}

\subsubsection{Sample Selection and Data Preprocessing}

The samples are private listed enterprises in China Small and Medium-sized Enterprise Board Market. After excluding finance companies, 'special treatment' stocks in 2013-2017, abnormal data loss, and enterprises with few samples, we get 2050 samples from 2013 to 2017. Both the financial data and the political connection information comes from the CSMAR database. The political connection indicators are calculated according to the political connection levels of the directors, supervisors, and executives.

This paper uses stata15.0 to measure accrual-based earnings management and real earnings management. Then, winsorize all the continuous variables with the upper and lower $1 \%$ quantiles, and carry out statistical analysis. Eventually, use Robust regression of least square method to find out the impact of political connection on earnings management.

\subsubsection{Variable Definition}

(1) Explained Variable

(1) Accrual-based earnings management. Referring to relevant literature, Jones model is used to measure earnings management, and its model is as follows:

$$
\frac{T A_{i, t}}{A_{i, t-1}}=a_{0} \frac{1}{A_{i, t-1}}+a_{1} \frac{\Delta R E V_{i, t}-\Delta R E C_{i, t}}{A_{i, t-1}}+a_{2} \frac{P P E_{i, t}}{A_{i, t-1}}+\varepsilon_{i, t}
$$

Among which: $\mathrm{TA}_{\mathrm{i}, \mathrm{t}}$ is the total amount of accrued profit in period $\mathrm{t}, \mathrm{TA}_{\mathrm{i}, \mathrm{t}}=\mathrm{NI}_{\mathrm{i}, t}-\mathrm{CFO}_{\mathrm{i}, \mathrm{t}}, \mathrm{NI}_{\mathrm{i}, \mathrm{t}}$ is the net profit in period $t, \mathrm{CFO}_{\mathrm{i}, \mathrm{t}}$ is the net operating cash flow in period $\mathrm{t} ; \mathrm{A}_{\mathrm{i}, \mathrm{t}-1}$ is the total assets at the end of the year in period $\mathrm{t}-1 ; \Delta \mathrm{REV}_{\mathrm{i}, \mathrm{t}}$ is the change in gross sales in period $\mathrm{t} ; \triangle \mathrm{REC}_{\mathrm{i}, \mathrm{t}}$ is the change in receivables in period $\mathrm{t} ; \mathrm{PPE}_{\mathrm{i}, \mathrm{t}}$ is the original value of fixed assets at the end of the year in period t. Parameters $\alpha_{0}, \alpha_{1}, \alpha_{2}$ can be calculated by the regression of the above model (4.1).

$$
\frac{N D A_{i, t}}{A_{i, t-1}}=a_{0} \frac{1}{A_{i, t-1}}+a_{1} \frac{\Delta R E V_{i, t}-\Delta R E C_{i, t}}{A_{i, t-1}}+a_{2} \frac{P P E_{i, t}}{A_{i, t-1}}
$$

Take the regression parameters into formula (4.2) to calculate the non-manipulative accrued profit NDA during the event period.

$$
D A_{i, t}=\frac{T A_{i, t}}{A_{i, t-1}}-\frac{N D A_{i, t}}{A_{i, t-1}}
$$

Finally, through formula (4.3), the total amount of the estimated accruals minus the non-manipulated accruals, we can get the manipulated accruals DA. It provides evidence that the increases in accrual-based earnings management when aDA is higher. 
(2) Real earnings management. In this paper, Roychowdhury (2006) real earnings management model is used to measure abnormal business activities' cash net flow, abnormal production costs, and abnormal discretionary costs. Then a comprehensive index is designed to reflect the overall real earnings management of the company by referring to the research of Cohen and others (2008). The model is as follows:

$$
\frac{C F O_{i, t}}{A_{i, t-1}}=\beta_{0} \frac{1}{A_{i, t-1}}+\beta_{1} \frac{S_{i, t}}{A_{i, t-1}}+\beta_{2} \frac{\Delta S_{i, t}}{A_{i, t-1}}+\varepsilon_{i, t}
$$

Model (4.4) is used to estimate the normal operating net cash flow. Among them, $\mathrm{CFO}_{\mathrm{i}, \mathrm{t}}$ is the operating net cash flow in period $t ; S_{i, t}$ is the sales revenue in period $t$; and $\Delta S_{i, t}$ is the changing amount in sales revenue in period $t$.

$$
\frac{P R O D_{i, t}}{A_{i, t-1}}=\beta_{0} \frac{1}{A_{i, t-1}}+\beta_{1} \frac{S_{i, t}}{A_{i, t-1}}+\beta_{2} \frac{\Delta S_{i, t}}{A_{i, t-1}}+\beta_{2} \frac{\Delta S_{i, t-1}}{A_{i, t-1}}+\varepsilon_{i, t}
$$

Model (4.5) is used to estimate the standard production cost. Among them, PROD $_{\mathrm{i}, \mathrm{t}}$ is the production cost in period $\mathrm{t}$, which is the sum of the current operating cost and inventory changing amount; and $\Delta \mathrm{S}_{\mathrm{i}, \mathrm{t}-1}$ is the changing amount in sales revenue in period $t-1$.

$$
\frac{D I S X_{i, t}}{A_{i, t-1}}=\beta_{0} \frac{1}{A_{i, t-1}}+\beta_{2} \frac{S_{i, t-1}}{A_{i, t-1}}+\varepsilon_{i, t}
$$

Model (4.6) is used to estimate the standard discretionary cost. Among them, DISX $\mathrm{i}_{\mathrm{i}, \mathrm{t}}$ is the discretionary expense in period $t$, which is the sum of current sales expense and management expense; $S_{i, t-1}$ is the sales revenue in period $\mathrm{t}-1$.

$$
R E M_{i, t}=R E M_{-} P R O D_{i, t}-R E M_{-} C F O_{i, t}-R E M_{-} D I S X_{i, t}
$$

Based on the above model, we can obtain the average estimates of net cash flow from operating (CFO), production cost (PORD), and discretionary expenses (DISX). Then, subtract the estimated value from the actual value of the company, and the difference between them is the abnormal values, which are net cash flow from abnormal operating activities (REM_CFO), abnormal production cost (REM_PORD) and abnormal discretionary expense (REM_DISX). The model (4.7) is used to design a general indicator REM to reflect the total amount of real earnings management. The larger the absolute value of this indicator (aREM) is, the higher the real earnings management level is.

\section{(2) Explanatory Variable}

Political connection (PC). This paper defines the political connection as, if the actual controller, director, and senior manager of the company once or now held positions in People's Congress, CPPCC, and people's government at all levels, then the company is considered to have a political connection. The paper does not consider executives without revealed political background or hidden executives. According to Song Lisheng's (2014) method of measuring political connection, we can calculate the index of the political connection of private enterprises. It can divide into central and decentralized levels according to the political backgrounds of senior executives, assigns values 4, 3, 2, 1, 0 from high to low. If the same senior manager holds multiple positions at the same time, it takes the highest value. Finally, sum up the political connection of all executives to get the company's current political connection level.

\section{(3) Control Variable}

Referring to the research of Hu Haibo and Liu Yan (2018), the paper chooses control variables in the following table. 
Table 1. Variable Definitions

\begin{tabular}{|c|c|c|c|}
\hline Variable Types & Names & Indicators & Definitions \\
\hline \multirow{2}{*}{ Response Variables } & $\begin{array}{c}\text { Accrual-based Earnings } \\
\text { Management }\end{array}$ & $\mathrm{aDA}$ & Modify the Jones model and take the absolute value. \\
\hline & Real Earnings Management & aREM & $\begin{array}{l}\text { Calculate by the Roychowdhury model and take the } \\
\text { absolute value }\end{array}$ \\
\hline $\begin{array}{r}\text { Explanatory } \\
\text { Variable }\end{array}$ & Political Connection & $\mathrm{PC}$ & $\begin{array}{l}\text { Assign values according to administrative level and } \\
\text { add up. }\end{array}$ \\
\hline \multirow{8}{*}{ Control Variables } & Profitability & ROE & $\begin{array}{l}\text { Return on equity calculated by dividing net income by } \\
\text { shareholders' equity }\end{array}$ \\
\hline & Solvency & Lev & Total liabilities divided by total assets (Debt ratio) \\
\hline & Enterprise size & Size & Natural logarithm of total assets \\
\hline & $\begin{array}{c}\text { Total Assets } \\
\text { Operating Capacity }\end{array}$ & Turn & $\begin{array}{l}\text { The operating return on assets is calculated by dividing } \\
\text { operating income by the total assets of the } \\
\text { business }\end{array}$ \\
\hline & Growth Capacity & Grow & Operating income growth rates \\
\hline & Executive Pay & Pay & $\begin{array}{l}\text { The natural logarithm of the total salary of the top } \\
\text { three executives }\end{array}$ \\
\hline & Industry & Industry & Industry dummy variables \\
\hline & Year & Year & Year dummy variables \\
\hline
\end{tabular}

\subsubsection{Model Design}

In order to verify the hypothesis 2 , which is the impact of political connection on the accrual-based earnings management of private enterprises, this paper establishes a model (4.8). When $\alpha_{1}$ is significantly negative, it shows that political connection is negatively related to the accrual-based earnings management of private enterprises, then the hypothesis 2 will be proved; otherwise, it will not be proved.

$$
\begin{gathered}
\mathrm{aDA}=\alpha_{0}+\alpha_{1} P C+\alpha_{2} \text { ROE }+\alpha_{3} \text { Lev }+\alpha_{4} \text { Size }+a_{5} \text { Turn }+a_{6} \text { Grow }+a_{7} \text { Pay }+ \\
\alpha_{8} \sum \text { Industry }+\alpha_{9} \sum \text { Year }+\varepsilon
\end{gathered}
$$

In order to verify the hypothesis 3 , which is the impact of political connection on the real earnings management of private enterprises, this paper establishes a model (4.9). When $\beta_{1}$ is significantly positive, it shows that political connection is positively correlated with the real earnings management behavior of private enterprises, then the hypothesis 3 will be proved; otherwise, it will not be proved.

$$
\begin{gathered}
\mathrm{aREM}=\beta_{0}+\beta_{1} P C+\beta_{2} \text { ROE }+\beta_{3} \text { Lev }+\beta_{4} \text { Size }+\beta_{5} \text { Turn }+\beta_{6} \text { Grow }+\beta_{7} \text { Pay }+ \\
\beta_{8} \sum \text { Industry }+\beta_{9} \sum \text { Year }+\varepsilon
\end{gathered}
$$

\subsection{Empirical Results and Analysis}

\subsubsection{Descriptive Statistics}

Table 2. Descriptive Statistics of Political Connection

\begin{tabular}{cccccc}
\hline & 2013 & 2014 & 2015 & 2016 & 2017 \\
\cline { 2 - 5 } Minimum Value & 0 & 0 & 0 & 0 & 0 \\
Maximum Value & 20 & 15 & 12 & 12 & 13 \\
Average Value & 3.3523 & 3.1440 & 1.7866 & 1.8231 & 1.7806 \\
Standard Deviation & 3.1278 & 2.8736 & 2.3625 & 2.3957 & 2.3959 \\
The Proportion of Politically & $75.07 \%$ & $75.06 \%$ & $50.62 \%$ & $49.53 \%$ & $47.96 \%$ \\
Connected Firms & & & & & \\
\hline
\end{tabular}

Table 2 makes a descriptive statistic of political connection based on the value of sample observations. It can be seen from the table that in the two years from 2013 to 2014, the proportion of politically connected firms had exceeded 70\%, which indicates that the political connection of executives was quite common, being twice more than that of enterprises without political connection. However, from 2015 to 2017, the proportion of politically connected firms dropped significantly, which maintained at 50\%, indicating that the enthusiasm of private listed 
companies in Small and Medium Boards to establish political connections has declined.

It is easy to see from the table that in recent years, the average value of political connection has continued to decline from 3.3 to 1.7 , indicating that the maximum and minimum values of political connection in different periods are quite different. The standard deviation is greater than 2 , indicating that there is a big difference in the level of political connection among different companies. As a whole, the total number of politically connected firms is 1206 , accounting for $58.83 \%$ of the total samples, which shows that the private listed companies of Small and Medium Boards in China have generally established political ties with the government.

Table 3. Descriptive Statistics of Overall Sample Observations

\begin{tabular}{ccccc}
\hline Variable & Average Value & Standard Deviation & Minimum Value & Maximum Value \\
\hline aDA & 0.0459 & 0.0399 & 0.0006 & 0.1873 \\
aREM & 0.2291 & 0.2239 & 0.0035 & 1.2701 \\
PC & 2.3166 & 2.6570 & 0.0000 & 11.0000 \\
ROE & 0.0787 & 0.0722 & -0.1696 & 0.2950 \\
Lev & 0.3644 & 0.1729 & 0.0454 & 0.7641 \\
Size & 21.9328 & 0.8179 & 20.2705 & 24.0937 \\
Turn & 0.669 & 0.404 & 0.152 & 2.714 \\
Grow & 0.213 & 0.367 & -0.393 & 2.258 \\
Pay & 14.27 & 0.600 & 12.86 & 15.81 \\
\hline
\end{tabular}

Table 3 is the results of a descriptive statistic of overall sample observations, involving the annual observation data of 2050 private listed companies in 2013-2017. From the results, we can see that the average value of accrual-based earnings management (aDA) and real earnings management (aREM) is 0.0459 and 0.2291 , respectively, which indicates that private listed companies generally have earnings management behaviours. The average value of aREM is significantly higher than $\mathrm{aDA}$, indicating that most private listed companies choose to use real earnings management. For the maximum and minimum values, the minimum value of aDA is 0.0006 , and the maximum value is 0.1873 , which shows that there are significant differences in the accrual-based earnings management among private listed companies, and the overall level is low. The minimum value of aREM is 0.0035 , and the maximum value is 1.2701 . In terms of standard deviation, its aDA and aREM are 0.0399 and 0.2239 , respectively, which shows that there are considerable differences in the profit manipulation by different private listed companies using earnings management. In conclusion, the usage frequency of real earnings management is higher than that of accrual-based earnings management, which verifies hypothesis 1.

Table 4. Verification of Average Value T on Dividing Groups

\begin{tabular}{|c|c|c|c|}
\hline Variable & $\begin{array}{c}\text { Average value } 1 \\
\text { with no political connection }\end{array}$ & $\begin{array}{c}\text { Average value } 2 \\
\text { with political connection }\end{array}$ & $\begin{array}{l}\text { Verification of } \\
\text { average value } \mathrm{T}\end{array}$ \\
\hline $\mathrm{aDA}$ & 0.0482 & 0.0444 & $0.0039 * *$ \\
\hline aREM & 0.210 & 0.242 & $-0.0324 * * *$ \\
\hline ROE & 0.0802 & 0.0776 & 0.00250 \\
\hline Lev & 0.352 & 0.373 & $-0.0208 * * *$ \\
\hline Size & 21.91 & 21.95 & -0.0377 \\
\hline Turn & 0.636 & 0.692 & $-0.056 * * *$ \\
\hline Grow & 0.224 & 0.205 & 0.0190 \\
\hline Pay & 14.31 & 14.24 & $0.072 * * *$ \\
\hline
\end{tabular}

Note: $* * * * * *$ are significant at the level of $1 \%, 5 \%$ and $10 \%$ respectively.

In Table 4, the sample private listed companies are divided into two groups according to whether there is a political connection, and the T-test is carried out based on the average value of the two groups. From the results in the table, we can learn that the difference of the average value of the accrual-based earnings management 
(aDA) is 0.0039 , and the listed companies without political connections are higher than that with political connections in the accrual-based earnings management. The result shows that political connection can indeed weaken accrual-based earnings management of private companies to a certain extent, which also preliminarily verifies the hypothesis 2 . The T-test of average values of real earnings management (aREM) explains that political connection could impel private corporates to adopt real earnings management more, which verifies the hypothesis 3 to some extent.

From the perspective of control variables, there is a significant difference in the asset-liability ratio (Lev), which argues that politically connected firms have a relatively higher asset-liability ratio because they can get sources of finance under the guarantee of the government. The differences of Return on Equity (ROE), assets scale (Size) and revenue growth rate (Grow) are not distinct, which shows that there are no significant differences in profitability, scale, and growth between politically connected firms and non-connected firms.

\subsubsection{Correlation Analysis}

Table 5. Verification of Correlation

\begin{tabular}{|c|c|c|c|c|c|c|c|c|c|}
\hline & $\mathrm{aDA}$ & aREM & $\mathrm{PC}$ & ROE & Lev & Size & Turn & Grow & Pay \\
\hline $\mathrm{aDA}$ & 1 & & & & & & & & \\
\hline aREM & 0.001 & 1 & & & & & & & \\
\hline PC & $-0.056 * *$ & $0.097 * * *$ & 1 & & & & & & \\
\hline ROE & -0.006 & $0.176^{* * *}$ & -0.022 & 1 & & & & & \\
\hline Lev & $0.080 * * *$ & 0.006 & $0.052 * *$ & $-0.060 * * *$ & 1 & & & & \\
\hline Size & 0.001 & $0.056 * *$ & 0.029 & $0.236 * * *$ & $0.514 * * *$ & 1 & & & \\
\hline Turn & 0.028 & $0.185^{* * *}$ & $0.069 * * *$ & $0.269 * * *$ & $0.206 * * *$ & $0.136 * * *$ & 1 & & \\
\hline Grow & $0.069 * * *$ & 0.033 & -0.035 & $0.284 * * *$ & $0.096 * * *$ & $0.195 * * *$ & $0.129 * * *$ & 1 & \\
\hline Pay & $-0.049 * *$ & $0.124 * * *$ & $-0.063 * * *$ & $0.302 * * *$ & $0.058 * * *$ & $0.385^{* * *}$ & $0.136 * * *$ & $0.097 * * *$ & 1 \\
\hline
\end{tabular}

Note: $* * *, * * *$ are significant at the level of $1 \%, 5 \%$ and $10 \%$ respectively.

Table 5 shows the Pearson correlation coefficients among the main variables in this paper. It can be seen from the table that there is a significant relationship between political connection (PC) of private listed companies and the accruals earnings management (aDA) and real earnings management (aREM). PC has a negative correlation with aDA at the significance level of 5\%, which shows that the political connection may weaken the accrual-based earnings management, in line with the expected assumption. PC and aREM have a significant positive correlation at the $1 \%$ level, which shows that the political connection promotes the real earnings management of enterprises.

At the same time, the explained variables aDA、aREM and the control variables Lev 、 ROE、, Size have significant relationships in varying degrees. Lev has a positive correlation with aDA which shows that the solvency is worse when the debt ratio is high, so the management team choose to adopt accrual-based earnings management. ROE is positively correlated with aREM at a significant level of $1 \%$, which indicates that enterprises tend to use real earnings management because of their high profitability. In addition, there is a significant correlation among Growth, Pay and accrual-based earnings management. There is a significant positive correlation between Turn and Pay and real earnings management, which shows that these control variables have a specific impact on earnings management of enterprises, so it is necessary to study them as control variables. Because correlation analysis is only a direct relationship between two variables, further regression is needed to get the results. From the perspective of the correlation coefficient, the correlation coefficient between control variables is lower than 0.6, which means there is no strong correlation, indicating that the possibility of collinearity in the model is low. 


\subsubsection{Regression Analysis}

Table 6. Regression results of political connection on different earnings management

\begin{tabular}{ccccc}
\hline & \multicolumn{2}{c}{$(1) \mathrm{aDA}$} & \multicolumn{2}{c}{ (2) aREM } \\
\hline & Coefficient & T-Value & Coefficient & T-Value \\
PC & $-0.0009^{* * *}$ & -2.75 & $0.0084 * * *$ & 4.40 \\
zzROE & -0.0049 & -0.27 & $0.4251^{* * *}$ & 5.26 \\
Lev & $0.0216^{* * *}$ & 3.10 & -0.0317 & -0.97 \\
Size & -0.0014 & -0.92 & $-0.0174 * *$ & -2.18 \\
Turn & $0.0046^{*}$ & 1.67 & $0.0321 * * *$ & 2.59 \\
Grow & $0.0073^{* *}$ & 2.49 & -0.0051 & -0.41 \\
Pay & $-0.0039^{* *}$ & -2.27 & $0.0360 * * *$ & 4.40 \\
_cons & $0.1230^{* * *}$ & 3.98 & -0.0091 & -0.05 \\
r2_a & & 0.0179 & & 0.1604 \\
\hline
\end{tabular}

Note: $* * *, * * *$ are significant at the level of $1 \%, 5 \%$ and $10 \%$ respectively.

Table 6 is the result of robust regression using the least square method of stata15.0 software, which corresponds to the regression results of model 4.8 and model 4.9, respectively. Results: (1) Political connection on the return of accrual-based earnings management. From the result (1), we can see that political connection (PC) has a negative impact on accrual-based earnings management (aDA) at a significant level of $1 \%$. Hence political connection can weaken the accrual earnings management, which is consistent with hypothesis 2. (2) Political connection on the return of real earnings management. From the result (2), we can see that political connection (PC) has a positive impact on real earnings management (aREM) at a significant level of $1 \%$. So political connection can promote the authenticity of earnings management, which is in line with hypothesis 3 . To sum up, private enterprises with political connections prefer to use real earnings management.

As for control variables, debt ratio (Lev) is positively related to aDA at a significant level of $1 \%$. Executives may have stronger motivation to use accrual-based earnings management for financial statements whitewash. The company size is negatively correlated with aDA and aREM. So, the bigger the company is, the more attention it receives from the public, which means the disclosure information need to be more transparent, of which the earnings management level is relatively low. Not only that, Pay has a significant negative correlation with aDA and a significantly positive correlation with aREM, which shows that executive compensation is also an essential factor affecting earnings management.

\subsubsection{Verification of Robustness}

The robustness of the verified results is tested as follows:

(1) Change the measurement method of political connection (PC) and set the explained variable PC as a dummy variable, assigning politically connected firms to 1 and non-connected firms to 0 . The regression results are as follows:

Table 7. Regression Results of Political Connection on Different Earnings Management

\begin{tabular}{ccccc}
\hline & \multicolumn{2}{c}{ (1) aDA aREM } \\
\hline PC & Coefficient & T-Value & Coefficient & T-Value \\
ROE & $-0.0044^{* *}$ & -2.37 & $0.0386^{* * *}$ & 4.31 \\
Lev & -0.0046 & -0.27 & $0.4276^{* * *}$ & 5.28 \\
Size & $0.0218^{* * *}$ & 3.12 & -0.0352 & -1.08 \\
Turn & -0.0014 & -0.95 & $-0.0155^{*}$ & -1.96 \\
Grow & $0.0046^{*}$ & 1.68 & $0.0326^{* * *}$ & 2.62 \\
Pay & $0.0074^{* *}$ & 2.53 & -0.0063 & -0.50 \\
cons & $-0.0039^{* *}$ & -2.36 & $0.0318^{* * *}$ & 3.93 \\
r2_a & $0.1241^{* * *}$ & 4.07 & 0.0098 & 0.06 \\
\hline
\end{tabular}

Note: $* * * * *, *$ are significant at the level of $1 \%, 5 \%$ and $10 \%$ respectively.

Table 7 shows the regression results after changing the measurement method of political connection, and the results are as follows: 
From the result (1), we can see that the political connection (PC) has a negative impact on Earnings Management $(\mathrm{aDA})$ at a significant level of $5 \%$. So political connection can weaken the accrual-based earnings management, which is consistent with hypothesis 2 .

From the result (2), we can see that political connection (PC) has a positive impact on real earnings management (aREM) at a significant level of $1 \%$. Consequently, political connection can promote the authenticity of earnings management, which is consistent with hypothesis 3, proving the results of this study are robust.

(2) To enhance the reliability of the research conclusion, we change the measurement method of accrual-based earnings management (aDA) to the extended Jones model, which takes intangible assets and other long-term assets into account. The specific model is as follows:

$$
\frac{T A_{i, t}}{A_{i, t-1}}=a_{0} \frac{1}{A_{i, t-1}}+a_{1} \frac{\Delta R E V_{i, t}-\Delta R E C_{i, t}}{A_{i, t-1}}+a_{2} \frac{P P E_{i, t}}{A_{i, t-1}}+a_{2} \frac{I A_{i, t}}{A_{i, t-1}}+\varepsilon_{i, t}
$$

Among them: $\mathrm{TA}_{\mathrm{i}, \mathrm{t}}$ is the total amount of accrued profits in period $\mathrm{t} ; \mathrm{A}_{\mathrm{i}, \mathrm{t}-1}$ is the total year-end assets in period $\mathrm{t}-1$; $\triangle R E V_{i, t}$ is the change in operating revenue in period $t ; \Delta R E C_{i, t}$ is the change in receivables in period $t ; P_{i, t}$ is the original year-end value of fixed assets in period $t ; \mathrm{IA}_{\mathrm{i}, \mathrm{t}}$ is the intangible assets and other long-term assets in period $\mathrm{t}$.

The results of further regression analysis are as follows:

Table 8. The regression results of political relevance on different earnings management

\begin{tabular}{ccccc}
\hline & \multicolumn{2}{c}{$(1) \mathrm{aDA} 2$} & \multicolumn{2}{c}{ (2) aREM } \\
\hline PC & Coefficient & T-Value & Coefficient & T-Value \\
ROE & $-0.0007^{* *}$ & -2.25 & $0.0086^{* * *}$ & 4.38 \\
Lev & -0.0032 & -0.18 & $0.4302^{* * *}$ & 5.33 \\
Size & $0.0180^{* * *}$ & 2.62 & -0.0334 & -1.03 \\
Turn & -0.0007 & -0.48 & $-0.0166^{* *}$ & -2.08 \\
Grow & 0.0028 & 1.07 & $0.0325^{* * *}$ & 2.64 \\
Pay & $0.0047^{*}$ & 1.83 & -0.0053 & -0.43 \\
cons & $-0.0031^{*}$ & -1.89 & $0.0324^{* * *}$ & 4.01 \\
r2_a & $0.0955^{* * *}$ & 3.19 & 0.0254 & 0.14
\end{tabular}

Note: $* * * * *, *$ are significant at the level of $1 \%, 5 \%$ and $10 \%$ respectively.

Table 8 is the regression results after changing the measurement method of accrual-based earnings management, and the results are as follows:

From the result (1), we can see that the political connection (PC) has a negative impact on accrual-based earnings management(aDA) at a significant level of $5 \%$. It shows that political connection can weaken the accrual-based earnings management, which is consistent with hypothesis 2 .

From the result (2), we can see that political connection (PC) has a positive impact on real earnings management (aREM) at a significant level of $1 \%$. So, political connection can promote the authenticity of earnings management, which is consistent with hypothesis 3 , proving the results of this study are robust.

\section{Summary and Conclusion}

\subsection{Summary}

Based on the perspective of political connection, this paper studies the private listed companies in the Small and Medium Board from 2013 to 2017, and empirically analyzes the relationship between political connection and earnings management of private enterprises. The results show that private enterprises in China have earnings management behaviours in spite of the increasing risk of recognition. Real earnings management is more covert and flexible, so private enterprises prefer to choose real earnings management to avoid being recognized by regulators.

Meanwhile, the political connection is negatively related to the accrual-based earnings management of private enterprises. It increases the risk of manipulating the accrual earnings to be recognized by the market with a potentially negative impact brought by the extra public attention. 
Moreover, the political connection is positively related to the real earnings management of private enterprises. It is a signal of the sustainable development of enterprises attracting more investors' attention. To maintain the reputation, enterprises usually choose real earnings management.

\subsection{Policy Suggestion}

Through this study, we find that there are political connections and earnings management behaviours in private listed companies, which might promote real earnings management level. The paper provides the following suggestions to promote the healthy development of private enterprises, in view of the problems that exist.

First of all, companies must improve the internal governance mechanism and optimize equity structure to reduce earnings management level. When internal control fails, the earnings management level would be correspondingly higher. Hence enterprises should focus on the operation of internal control, which is of considerable significance to protect the legitimate rights and interests of investors and ensure the healthy development of the company. Much focus on the ownership structure is needed to prevent significant shareholders from manipulating the corporates' earnings to maximize personal interests, which affects the sustainable development of the enterprise. Companies need to reasonably arrange the ownership structure, avoiding the situation of one-share dominance, improve the independent director system, and supervise the decision-making processes.

Strengthen external supervision and improve the supervision mechanism. The external supervision is divided into two aspects: the government and society. The government supervision needs a reasonable division of labour, the establishment of post responsibility system, and strengthening information communication. At the same time, there should be close supervision over false information, protecting the interests of investors. Social supervision includes certified practising accountant (CPA) and public opinion. CPA is a vital supervision force for the external supervision of listed companies. They need to continually update their professional knowledge and improve their professional judgment ability to ensure the rights of investors.

Establish a fair institutional environment. The government should improve relevant laws and legislation to help enterprises develop. Specifically, the government can issue some policies and regulations for the establishment of a developed capital market that protect the development of the private economy. The government should strengthen the institutional construction, where can encourage private firms to speed up their reform. As for enterprises, they should maximize resources for technical innovation or other aspects which are conducive to long-term development. Only in this way can private enterprises have a more sustainable and healthy development, reduce earnings management behaviours, and improve the overall welfare of society.

\section{References}

Cao, R., Mu, S. H., \& Zhu, C. X. (2019). Review of Research on Accrual Earnings Management and Real Earnings Management. Modern Accounting, 2, 18-21.

Chaney, P. K., Faccio, M., \& Parsley, D. (2011). The quality of accounting information in politically connected firms. Journal of Accounting and Economics, 51(1-2), 58-76. https://doi.org/10.1016/j.jacceco.2010.07.003

Claessens, S., Feijen, E., \& Laeven, L. (2008). Political connections and preferential access to finance: The role of campaign contributions. Journal of Financial Economics, 88(3), 554-580. https://doi.org/10.1016/j.jfineco.2006.11.003

Cohen, D. A., Dey, A., \& Lys, T. Z. (2007). Real and Accrual-Based Earnings Management in the Pre- and Post-Sarbanes Oxley Periods (June 2007). AAA 2006 Financial Accounting and Reporting Section (FARS) Meeting Paper. https://doi.org/10.2139/ssrn.813088

Cui, M. (2018). Research on the Relationship among Political Connection, Media Coverage,and Earnings Management Method. North China University of Water Resources and Electric Power.

Faccio, M. (2006). Politically Connected Firms. American Economic Review, 96(1), 369-386. https://doi.org/10.1257/000282806776157704

Healy, P. M., \& Wahlen, J. M. (1998). A Review of the Earnings Management Literature and its Implications for Standard Setting (November 1998). https://doi.org/10.2139/ssrn.156445

Hu, H. B., \& Liu, Y. (2018). The Impact of Accrued Earnings Management and Real Earnings Management on Audit Fees In State - owned Enterprises. Journal of Hunan University of Finance and Economics, 34(06), 87-93.

Hu, X. Y. (2010). Political Connection of Private Enterprises and its Economic Effect. Economic Theory and 
Business Management, 02, 74-79.

Li, C. T., Zhao, Y., Xu, X., \& Li, Q. Y. (2016). Discourage One to Encourage Another: Analysts Following and Corporate Earnings Management Strategy. Journal of Financial Research, 4, 144-157.

Li, L. (2018). Risk Tolerance Level of Listed Companies, Choice of Earnings Management Methods and Company Value. Finance and Accounting Monthly, 08, 34-42.

Song, L. S., \& Wang, A. G. (2014). Political Connection of Ultimate Controlling Shareholder, Accounting Information Quality and Auditing of Certified Public Accountant: Evidence from Private Listed Companies. Journal of Audit \& Economics, 29(03), 40-49.

Sun, J. P. (2018). Review of Research on Influencing Factors of Earnings Quality. Economic \& Trade Update, 26(1), 28-29.

Tao, X. H. (2018). Political Connections and Earnings Management: Evidence from China. Review of Industrial Economics, 04, 30-44.

Wang, J. S., Shi, J. C., \& Li, Y. C. (2005). The Industrial Structure Evolution of China's Private Economy. Management World, 10, 82-93.

Wang, L. C. (2014). Accrued and Real Earnings Management: Substitutional or Complementary. The Theory and Practice of Finance and Economics, 2, 66-72.

Wang, X. Y. (2018). Research on the Relationship between Equity Pledge and Earnings Management in Private Enterprises — Based on the perspective of political connection. University of Electronic Science and Technology of China. Retrieved from https://ssrn.com/abstract=813088

Zhang, D. L., \& Liu, Y. Z. (2016). Do Private Enterprises Have Choice Preference of Methods of Earnings Management? From the Perspective of Political Connections. Finance and Trade Research, 04, 147-156.

Zhang, W. Q. (2019). Earnings Management and Governance Countermeasures of Listed Company. Accounting Learning, 07, 109-110.

\section{Copyrights}

Copyright for this article is retained by the author(s), with first publication rights granted to the journal.

This is an open-access article distributed under the terms and conditions of the Creative Commons Attribution license (http://creativecommons.org/licenses/by/4.0/). 